\title{
Granulomatous mastitis: A retrospective review of 49 patients
}

\section{Granülamatöz, mastit: 49 hastanın retrospektif incelenmesi}

\author{
Sadullah Girgin', Ömer Uslukaya ${ }^{1}$, Edip Erdal Yılmaz², Uğur Fırat ${ }^{3}$, Hatice Gümüşş, \\ Murat Kapan ${ }^{1}$, Metehan Gümüş ${ }^{1}$
}

\begin{abstract}
Objective: Idiopathic granulomatous mastitis, a rare, benign, chronic inflammatory condition of the breast, which usually mimics breast carcinoma. In this study, we report on the management of 49 cases of idiopathic granulomatous mastitis and their clinical presentation.
\end{abstract}

Methods: The breast and anatomical databases of one center were reviewed from 2007 to 2012 to identify patients with histological diagnosis of idiopathic granulomatous mastitis. Clinical and demographic characteristics were retrieved and treatment modalities were were recorded.

Results: The mean patient age was $37.71 \pm 7.1$ years. There were no differences between the management groups about etiological and demographic factors. The rate of recurrence in group 1, group 2, and group 3 was $8.3 \%, 14.8 \%$ and $20 \%$, respectively; there were no statistically significant difference among the groups.

Conclusion: Steroids and surgical methods codified in idiopathic granulomatous mastitis may be preferred. We recommend steroid therapy as first-line treatment. However, prospective, randomized clinical trials are needed to determine the treatment algorithm.

Key words: Idiopathic, granulomatous, mastitis, management

\section{INTRODUCTION}

Idiopathic granulomatous mastitis (IGM), also known as granulomatous lobular mastitis, is a rare benign inflammatory disease of the breast. It has a poorly understood etiology and unpredictable duration, and there is no consensus on optimal treatment [1-4]. Breast surgeons are usually adept at managing women with breast cancer and keep abreast of

\section{ÖZET}

Amaç: İdiopatik granulomatöz mastit, nadir görülen, benign, kronik inflamatuar bir hastalık olup meme kanserini taklit eder. Bu çalışmada idiopatik mastitli 49 hastanın tedavisini ve kliniğini sunmayı amaçladık.

Yöntemler: Hastane otomasyon sisteminde 2007-2012 yılları arasında histolojik olarak granulomatöz tanısı konulmuş hastalar incelendi. Hastalara ait klinik bulgular, demografik veriler ve tedavi yöntemleri kaydedildi.

Bulgular: Ortalama yaş $37.71 \pm 7.1$ idi. Tedavi gruplar arasında etiyolojik ve demografik açıdan istatistiksel fark yoktu. Nüks oranları grup 1, grup 2 ve grup 3'te sırasıyla $\% 8,3, \% 14,8 \% 20$ olup, gruplar arasında istatistiksel anlamlı farklılık yoktu.

Sonuç: Steroid ve cerrahi tedavinin idiopatik granulomatöz mastitli hastalarda uygulanabileceğini, steroid tedavisinin ilk basamak tedavi olması gerektiği kanaatindeyiz. Bununla birlikte tedavi algoritması belirlenebilmesi için prospektif, randomize klinik çalışmalara intiyaç vardır.

Anahtar kelimeler: İdyopatik, granülamatöz mastit, tedavi.

the evidence (Figure 1). Benign breast disorders, however, form a significant majority of the conditions presented to the breast surgeon and there is often a paucity of literature and evidence to manage these potentially more difficult diseases. Idiopathic granulomatous mastitis is rare and is a great mimicker of other breast conditions including breast carcinoma [5]. If not managed cautiously and thoroughly, treatment of IGM may require mastectomy.

${ }^{1}$ Departmant of General Surgery, Dicle University Medical Faculty, Diyarbakir, Turkey

${ }^{2}$ Departmant of General Surgery, Diyarbakır State Hospital, Diyarbakir, Turkey

${ }^{3}$ Departmant of Pathology, Dicle University Medical Faculty, Diyarbakir, Turkey

${ }^{4}$ Departmant of Radiology, Dicle University Medical Faculty, Diyarbakir, Turkey

Yazışma Adresi /Correspondence: Sadullah Girgin,

Dicle Üniversitesi Tıp Fakültesi, Genel Cerrahi Anabilim Dalı, Diyarbakır, Türkiye Email: sadullahgirgin@gmail.com

Geliş Tarihi / Received: 16.01.2015, Kabul Tarihi / Accepted: 26.02.2015

Copyright @ Dicle Tıp Dergisi 2015, Her hakkı saklıdır / All rights reserved 


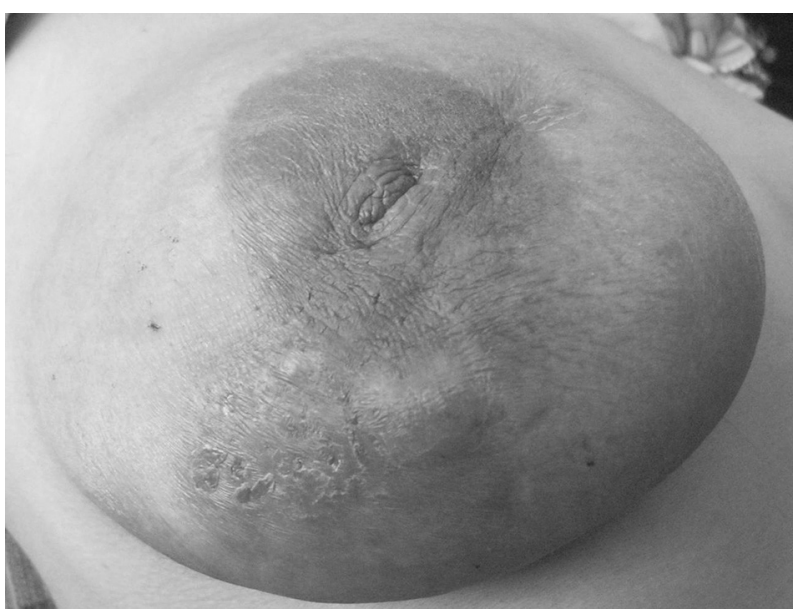

Figure 1. A photograph of the patient's left breast . Clinical appearance of the patient's breast including skin abscesses and fistulae. Photo obtained during her hospital admission

Although surgical excision and steroid therapy are the most commonly used treatments, different management options may be implemented. These include conservative approaches with close surveillance, wide excision, abscess drainage, mastectomy, and immunosuppressive therapy [6-9]. However, there is no consensus on the optimal treatment of patients with IGM [10-11]. Furthermore, reported rates of recurrence with IGM are as high as $50 \%$ [12]. In this study, we report on the management of 49 cases of IGM and their clinical presentation.

\section{METHODS}

This study included 49 women who met the required histological criteria of IGM and were treated between 2007 and 2012 in Dicle University Medical School Hospital. The design of the study has been approved by Dicle University Faculty of Medicine ethics committee and thus meets the standards of the Declaration of Helsinki. Due to retrospective nature of the study, the ethics committee did not require a written consent from the participants. During this period, each case of idiopathic granulomatous mastitis was diagnosed from among the 1,587 patients treated for breast pathologies. Diagnostic and therapeutic management of all 49 patients was undertaken by the same team.

We recorded a variety of etiologic factors, including: smoking; use of oral contraceptives; local trauma; time to presentation since last delivery or breast feeding; family history of breast cancer; tu- berculosis contact history; history of autoimmune disease; presenting symptoms; clinical findings (including size of lesion, the presence of an abscess, or sinus formation); radiographic, histological, and microbiological results; treatment modalities; and follow-up recurrence data.

All patients underwent a clinical breast examination and ultrasonography (USG) examination, while patients older than 40 years of age also underwent mammography. On suspicion of malignancy, magnetic resonance imaging (MRI) was performed for further investigation. Definitive diagnosis was obtained by core needle biopsy (14-gauge) or surgical excision or from biopsy specimens taken from the abscess wall during surgical drainage. The obtained specimens were fixed overnight in $10 \%$ formalin, and the residual tissues were cultured for bacteria. Paraffin-embedded specimens were stained with hematoxylin and eosin, Ziehl-Neelsen, and the periodic acid-Schiff reaction with or without diastase digestion. Other possible causes of granulomatous inflammatory lesions of the breast were excluded by serological tests, histological analysis, and tests of the affected tissue for aerobic and anaerobic bacteria, mycobacteria, and fungi.

Group 1 had twelve patients that were only given medical treatment in the form of steroid therapy at $32 \mathrm{mg} /$ day depending on the dimensions of the lesion the severity of symptoms, and the patient's general health and personal treatment preferences. Group 2 (27 patients) underwent surgical excision. In group 3 (10 patients), breast abscesses were drained as an initial treatment step for those patients that had them. In addition, group 3 patients also received antibiotic therapy (as did any patient with positive microbiological culture) and steroid therapy at $32 \mathrm{mg} /$ day after the regression of inflammatory process.

Patients who had receiving steroid treatment and the dosage of steroid were monitored monthly until remission. Once remission was achieved, monitoring and dosage control was adjusted every 3 month for the first year; after the first year, they were controlled on a yearly basis. All patients were assessed on follow-up by physical examination, USG, and laboratory tests (including $\mathrm{C}$ reactive protein, ESR, white blood cell count, and alkaline phosphatase). 
Remission was conceptualized as a complete absence of disease activity, with no signs or symptoms of active disease. Practically, the patients would need to meet the following criteria to be considered in remission:

- Clinical criteria: No tender or swollen mass on physical exam.

- Laboratory criteria: Normal C reactive protein, ESR, white blood cell count, and alkaline phosphatase.

- Radiological: Absence of ultrasound finding

- Duration: At least three weeks of meeting the above criteria.

\section{Statistical analysis}

Statistical analysis was performed by SPSS for Windows 13.0 (SPSS Inc., Chicago, IL, USA). Data were expressed as the mean \pm SD (standard deviation) values for continuous values. Chi-square test was used for categorical variables. Groups were compared by using the non-parametric KruskalWallis test. The Mann-Whitney U test was used for continuous data that did not meet a normal distribution. P-value of less than 0.05 was considered significant.

\section{RESULTS}

All patients were female and the median age at the time of diagnosis was $37.71 \pm 7.1$ years $(24-57$ years). Patients' mean ages in group 1, group 2, and group 3 were $35.42 \pm 6.37,39 \pm 7.94$ and $36.90 \pm 4.97$ years old, respectively, without significant statistical difference between the groups $(p=0.350)$. Most of the patients ( 42 of the 49 ) were at a reproductive age. All patients were less than five years removed from a previous pregnancy (average 26 months) and had a history of breast feeding. Average duration of breast feeding was 17 months (with a range of 4-34 months). Eight patients (16.3\%) reported use of tobacco products and nine $(18.4 \%)$ reported prior use of oral contraceptive pills. None of the patients had local trauma, family history of breast cancer, tuberculosis contact history, history of autoimmune disease, history of diabetes mellitus, or alpha-1 antitrypsin deficiency. The mean duration of symptoms was nine weeks (with a range of 20 days to 9 months) before presentation. Twenty-three patients $(47 \%)$ had already been treated with antibiotics before presentation to our department.

Table 1. Summary of the characteristics of patients with idiopathic granulomatous mastitis

\begin{tabular}{|c|c|c|c|c|c|}
\hline Type of treatment & $\begin{array}{l}\text { All groups } \\
(n=49)\end{array}$ & $\begin{array}{l}\text { Group } 1 \\
\text { Steroid } \\
(n=12)\end{array}$ & $\begin{array}{c}\text { Group } 2 \\
\text { Surgical } \\
(n=27)\end{array}$ & $\begin{array}{c}\text { Group } 3 \\
\text { Drainage + } \\
\text { Steroid } \\
(n=10)\end{array}$ & $P$ value \\
\hline Age (year), (Range) & $37.7 \pm 7.1(24-57)$ & $35.4 \pm 6.4(24-43)$ & $39 \pm 7.9(26-57)$ & $36.9 \pm 4.9(31-45)$ & NS \\
\hline Size of lesion (cm), (Range) & $4.0 \pm 2.3(1.3-13)$ & $3.2 \pm 0.8(15-4)$ & $3.9 \pm 2.3(1.3-10)$ & $5.3 \pm 3.0(2-13)$ & NS \\
\hline Number of lesions (Range) & $1.2 \pm 0.5(1-3)$ & 1 & $1.3 \pm 0.6(1-3)$ & $1.1 \pm 0.3(1-2)$ & NS \\
\hline Breast-feeding (month) (Range) & $17.0 \pm 7.3(3-32)$ & $16.5 \pm 5.7(11-28)$ & $17.89 \pm 8.09(3-32)$ & $15.3 \pm 6.86(6-25)$ & NS \\
\hline Use of tobacco products, $\mathrm{n}(\%)$ & $8(16.3)$ & - & $6(22.2)$ & $2(20)$ & NS \\
\hline Oral contraceptive usse, $\mathrm{n}(\%)$ & $9(18.4)$ & $1(8.3)$ & $7(25.9)$ & $1(10)$ & NS \\
\hline Lymphadenopathy, n (\%) & $6(12.2)$ & - & $2(7.4)$ & $4(40)$ & 0.009 \\
\hline Fever, n (\%) & $9(18.4)$ & $1(8.3)$ & $2(7.4)$ & $6(60)$ & 0.001 \\
\hline $\begin{array}{l}\text { Painful/erythematous } \\
\text { breast lesions, } \mathrm{n}(\%)\end{array}$ & $16(32.7)$ & $3(25)$ & $3(11.1)$ & $10(100)$ & $<0.001$ \\
\hline Nipple discharge, n (\%) & $5(10.2)$ & - & $3(11.1)$ & $2(20)$ & NS \\
\hline Presence of skin fistula, n (\%) & $7(14.3)$ & $1(8.3)$ & $6(22.2)$ & - & NS \\
\hline Recurrence, n (\%) & $7(14.3)$ & $1(8.3)$ & $4(14.8)$ & $2(20)$ & NS \\
\hline
\end{tabular}

$N S=$ not significant $(p>0.05)$

The left breast was affected in 29 patients $(59 \%)$ and the right breast in 20 patients $(41 \%)$.
All patients presented with palpable breast lumps in the absence of constitutional symptoms. Pain- 
ful and/or erythematous breast lesions, fever and lymphadenopathy symptoms were significantly higher patients from group $3(\mathrm{p}<0.0001, \mathrm{p}=0.001$ and $p<0.009$ respectively). There were no differences between the groups about etiological and demographic factors. The rate of recurrence in group 1 , group 2, and group 3 was $8.3 \%, 14.8 \%$ and $20 \%$, respectively; there were no statistically significant difference among the groups. Remission occurred by surgical excision at three patients with relapses in group 1 and group 3; and by steroid treatment at four patients with relapses in group 2. All patients in group 1 had only one lesion and there was no tobacco use, nipple discharge, or lymphadenopathy (Table 1). Steroid treatment period were $7.52 \pm 1.6$ months at group 2 and were $7 \pm 1.7$ months at group 3 as there were no statistically significant difference between the groups $(p>0.05)$. Complications due to steroid treatment were observed in only two patients who developed a moon face and acne. Mean follow up for all groups was 48 months.

\section{DISCUSSION}

IGM, a rare benign breast disease, was first described in 1972 by Kessler and Wolloch [13]. It is a benign inflammatory breast disease that often clinically simulates carcinoma. Few articles exist in the literature, and most of those are case reports and include only small series of patients [14]. Our series of 49 patients is one of the largest single-institution series reported to date in Turkey. Similar to other published series, the age at presentation was between 24 and 57 years; however, patients as young as 11 and as old as 83 years have been reported [14$15]$.

IGM is characterized by the presence of epithelioid and multinucleated giant cell granulomas limited to the mammary lobules with micro-abscesses in the absence of obvious etiology [16]. Local or systemic irritants as well as undetected infective causes may result in damage to the ductal epithelium. Luminal fat and protein rich secretion into the lobular connective tissue produces a localized granulomatous response [17]. This association has recently been challenged, because serologic and bacterial tests are usually negative in patients presenting with IGM [8]. Also, some authors have suggested that the prior use of oral contraceptives, a history of breast feeding, and pregnancy are linked to IGM. Many women with IGM breast-fed their children and the majority of those that breast-fed were pregnant or lactating in the five years prior to the onset of IGM symptoms [18]. High serum prolactin levels, as well as distention of the acini and ducts may result in a rupture of these structures, inducing a granulomatous response $[19,20]$. In our series, nine patients (18.4\%) had previously used oral contraceptive pills and eight patients $(16.3 \%)$ had a history of using tobacco products.

Idiopathic granulomatous mastitis usually presents with a unilateral, firm, discrete, tender mass, ranging from 0.5 to $10 \mathrm{~cm}$ in size. Overlying skin is often inflamed, though it can sometimes present with a non-tender mass or pain alone. Nipple retraction and discharge, sinus formation, and axillary lymphadenopathy may be seen [17]. In the literatu$\mathrm{re}$, the most common presentation symptoms have been reported as a mass in the breast (48-100\%), sinus or abscess (16-52\%), and inflammation or erythema $(11 \%)[6,17,20]$. In this study, all patients had unilateral breast mass. However, lymphadenopathy, pain, erythematous breast lesions, and fever seen most frequently in patients who had breast abscess.

Mammography, ultrasonography, and MRI are used primarily to rule out malignancy and confirm a diagnosis of IGM. The mammographic findings of IGM are not well documented and often mimic breast carcinoma $[1,2]$. The USG appearance of IGM is non-specific, non-homogeneous, irregular hypoechoic lesion with focal posterior shadowing [21]. The appearance of multiple clustered, often contiguous, hypoechoic tubular lesions, associated with a large hypoechoic mass has been considered to be suggestive of the condition, but these features are not always found [22]. MRI shows a focal homogeneous enhancing mass with irregular borders and parenchymal distortion, but it is difficult to differentiate GM from breast cancer based on such MRI findings [3]. The role of MRI in the characterization of inflammatory processes of the breast is non-specific, but it is still useful in patients who have no significant pathology on mammography or USG $[1,2,17]$. MRI is also reported to provide no additional information for the differentiation of mastitis from carcinoma. This process has high sensitivity, but low specificity for most breast lesions [14]. 
Other causes of granulomatous lesions in the breast that require different treatments must be excluded. These include infective causes such as tuberculosis or brucellosis, parasitic infections such as filariasis, fungal infections such as actinomycosis, and systemic diseases such as sarcoidosis, Wegener's granulomatosis, or giant-cell arteritis $[13,23]$. Foreign-body reaction, fat necrosis, and ductal ectasia must also be excluded [2,13]. Since clinical and imaging diagnoses are often difficult and inconclusive, histopathologic evaluation plays a crucial role in diagnosing IGM. Diagnosis can be challenging and cytological features can be difficult to distinguish from those of carcinoma and other granulomatous disease of the breast, such as specific infections (mycobacterium tuberculosis, fungus, parasites), duct ectasia, periductal mastitis, plasmacell mastitis, sarcoidosis, and vasculitis $[11,24]$. Tuberculosis must be considered in the differential diagnosis, especially since it is more prevalent in an endemic region like ours, southeastern Turkey. In the published literature, most diagnoses of IGM are based upon ruling out tuberculosis by histochemical staining and clinical evaluation $[6,25]$. Chest X-ray, tuberculin skin test, Quantiferon assay, determination of erythrocyte sedimentation rate, and PCR may also aid in diagnosis [26].

The optimal treatment approach for IGM has not yet been established; research is limited by an insufficient number of diagnoses. Available treatment options include close follow-up, antibiotic therapy, surgical excision, steroids, and immunosuppressive drugs $[9,25,27,28]$. The management of patients with IGM varies broadly from conservative approaches to mastectomy $[1,14]$. Lai et al. [15] reported spontaneous resolution in four of eight cases of IGM with a mean interval of 14.5 months for complete resolution. Wide surgical excision is traditional and the most commonly performed surgical intervention [4]. Although limited excision may be possible, complete excision of the breast mass or involved inflammatory tissue provides more satisfactory results in terms of preventing further complications and recurrence [1,9]. Breast abscesses must initially be drained. The role of antibiotics in the treatment of IGM is of little value [12]. Antimicrobial therapy should be administered in cases of positive culture results for the biopsy samples. In the case of abscess or sinus formation, 2 weeks empiric antibiotic treatment is also recommended [27].

DeHertogh et al. in 1980 were the first who investigated the efficacy of different treatments and they concluded that corticosteroid is an appropriate option for the treatment of the disease. Furthermore, Sakurai et al. sought this pharmaceutical approach and they authenticated that corticosteroid could be efficient in $87 \%$ of patients without any relapse. The proceeded results were validated by Hisuing et al. while their research implied that low doses of corticosteroids were efficient; though, more investigations in this field were recommended by them. Moreover, in 2010, it was authenticated that corticosteroids provide appropriate treatment, whereas first option should be allocated to surgery in the case of relapse, fistula, and abscess [21]. Pandey et al.14 described their prospective study of 49 women with a mean age of 35 years and found that $80 \%$ were of Hispanic origin $(\mathrm{OR}=3.00,91 \%$ CI $1.42-6.24, \mathrm{P}$ $=0.0032), 80 \%$ presented with a painful mass and $90 \%$ were prescribed steroids with an $80 \%$ complete resolution rate. It should be kept in mind that steroids may exacerbate infectious disease of the breast; therefore, it is essential to exclude an infectious etiology before giving steroids. Furthermore, the side effects of steroid therapy can include glucose intolerance, acne and cushingoid features [5].

Based on our findings, oral corticosteroids and surgery have both been used as treatment options. Because recurrence ratios were the same. The surgical approach should be considered in the following circumstances: the presence of contraindications or complications of corticosteroid therapy; failure to achieve the desired benefits in long-term treatment; or the patient requests surgery. We advise steroid treatment after surgical or radiological drainage with antibiotherapy to the patients which have cavities or abscess formation. In the study, recurrences were seen at two of the patients with abscess formation and they were treated with extensive surgical excision. We mostly do not advise extensive surgical excision primarily to the patients which have large cavities or abscess formation. The recurrences at four patients who had surgical treatment before were treated with steroids and the recurrences at two patients who had steroid treatment before were treated with steroids surgical excision successfully. 
So we think that these treatments can be alternatively used with the patients who have recurrences. In our study, the recurrence at one patient who had steroid treatment before were treated surgically and the recurrence at four patients who had treatment surgically before were treated with steroids successfully.

This study shows that both of surgical and steroid treatments can be used for granulomatous mastitis. But as there is no statistically significant difference about the recurrence ratios, it can be concluded that steroid treatment should be used primarily and surgical treatment should be used at the patients with recurrences, when the side effects and also resistance are occurred with steroids.

There is still not a commonly accepted optimal treatment plan for IGM. Wide local excision and/or corticosteroid administration has been reported for the first line treatment of IGM. The wide spectrum of clinical signs, symptoms, and course of IGM make it difficult to choose and standardize a favorable treatment. Which one of the treatment modalities is favorable? When should wide local excision or corticosteroids be preferred? Is it best to administer the same dose of corticosteroids for the same duration for all patients? What should be done if patient is reluctant to accept corticosteroid therapy? Clearly, there is a need for prospective randomized trials comparing conservative approach, wide local excision, and corticosteroid therapy to optimize and standardize the diagnosis and treatment of IGM. Nevertheless, it may be possible to compose a mandatory treatment algorithm for IGM.

\section{REFERENCES}

1. DeHertogh DA, Rossof AH, Harris AA, Economou SG. Prednisone management of granulomatous mastitis. N Engl J Med 1980;303:799-800.

2. Fletcher A, Magrath IM, Riddell RH, Talbot IC. Granulomatous mastitis: a report of seven cases. J Clin Pathol 1982;35:941-945.

3. Going JJ, Anderson TJ, Wilkinson S, Chetty U. Granulomatouslobular mastitis J Clin Pathol 1987;40:535-540.

4. Jorgensen MB, Nielsen DM. Diagnosis and treatment of granulomatous mastitis. Am J Med 1992;93:97-101.

5. Skandarajah A, Marley L. Idiopathic granulomatous mastitis:a medical or surgical disease of the breast? ANZ J Surg 2014; 24:234-239. doi: 10.1111/ans. 12929.

6. Afridi SP, Memon A, Shafiq-ur-Rahman, Memon A. Granulomatous mastitis: a case series. J Coll Physicians Surg Pak 2010;20:365368.

7. Sellitto A, Santoriello A, De Fanis U, et al. Granulomatous lobular mastitis: another manifestation of systemic lupus erythematosus? Breast J 2013;19:331-332.
8. Gurleyik G, Aktekin A, Aker F, et al. Medical and surgical treatment of idiopathic granulomatous lobular mastitis: a benign inflammatory disease mimicking invasive carcinoma. J Breast Cancer 2012;15:119-123.

9. Bani-Hani KE, Yaghan RJ, Matalka II, Shatnawi NJ. Idiopathic granulomatous mastitis: Time to avoid unnecessary mastectomies. Breast J 2004;10:318-322.

10. Kok KY, Telisinghe PU. Granulomatous mastitis: presentation, treatment and outcome in 43 patients. Surgeon 2010;8:197-201.

11. Sakurai K, Fujisaki S, Enomoto K, et al. Evaluation of follow-up strategies for corticosteroid therapy of idiopathic granulomatous mastitis. Surg Today 2011;41:333-337.

12. Altintoprak F, Kivilcim T, Ozkan OV. Aetiology of idiopathic granulomatous mastitis. World J Clin Cases 2014;2:852-858. doi: 10.12998/wjcc.v2.i12.852.

13. Erhan Y, Veral A, Kara E, et al. A clinicopathologic study of a rare clinical entity mimicking breast carcinoma: idiopathic granulomatous mastitis. Breast. 2000;9:52-56.

14. Asoglu O, Ozmen V, Karanlik H, et al. Feasibility of surgical management in patients with granulomatous mastitis. Breast J 2005;11:108-114.

15. Lai ECH, Chan WC, Ma TK, et al. The role of conservative treatment in idiopathic granulomatous mastitis. Breast J 2005;11:454456.

16. Casteren CV, Jacquemyn Y, Himpe E, Verslegers I. Idiopathic ganulomatous mastitis. BMJ Case Rep 2012. doi: 10.1136/bcr-2012006187.

17. Ocal K, Dag A, Turkmenoglu O, et al. Granulomatous mastitis: clinical, pathological features, and management. Breast J. 2010;16:176-182.

18. Gautier N, Lalonde L, Tran-Thanh D, et al. Chronic granulomatous mastitis: Imaging, pathology and management. Eur J Radiol. 2013;82:e165-175.

19. Ozel L, Unal A, Unal E, et al. Granulomatous mastitis: is it autoimmune disease? diagnostic and therapeutic dilemmas. Surg Today 2012;42:729-733.

20. Kiyak G, Dumlu EG, Kilinc I, et al. Management of idiopathic granulomatous mastitis: dilemmas in diagnosis and treatment. BMC Surg 2014;14:66. doi: 10.1186/1471-2482-14-66.

21. Salehi M, Salehi H, Moafi M, et al. Comparison of the effect of surgical and medical therapy for the treatment of idiopathic granulomatous mastitis. J Res Med Sci. Mar 2014;19:5-8.

22. Memis A, Bilgen I, Ustun EE Ozdemir N, et al. Granulomatous mastitis: imaging findings with histopathologic correlation. Clin Radiol 2002;57:1001-1006.

23. Wilson JP, Massoll N, Marshall J, et al. Idiopathic granulomatous mastitis: in search of a therapeutic paradigm. Am Surg. 2007;73:798-802.

24. Heer R, Shrimankar J, Griffith CDM. Granulomatous mastitis can mimic breast cancer on clinical, radiological or cytological examination: a cautionary tale. Breast 2003;12:283-286.

25. Guven HE, Pak I, Oral S. Granulomatous mastitis: surgical outcomes. J Coll Physicians J Coll Physicians Surg Pak 2006;16:431433.

26. Joseph KA, Luu X, Mor A. Granulomatous Mastitis: A New York Public Hospital Experience. Ann Surg Oncol 2014. doi:10.1245/ s10434-014-3895-z.

27. Al-Khaffaf B, Knox F, Bundred NJ. Idiopathic granulomatous mastitis: a 25-year experience. J Am Coll Surg 2008;206:269-273.

28. Pereira FA, Mudgil AV, Macias ES, Karsif K. Idiopathic granulomatous lobular mastitis. Int J Dermatol 2012;51:142-151.

29. Pandey TS, Mackinnon JC, Bressler L, et al. Idiopathic granulomatous mastitis - a prospective study of 49 women and treatment outcomes with steroid therapy. Breast J 2014;20:258-266. 